\title{
Evidence for Viral Induction of Biliary Atresia: A Review
}

\author{
Leon D. Averbukh* and George Y. Wu \\ Department of Medicine, Division of Gastroenterology-Hepatology, University of Connecticut Health Center, Farmington, CT, USA
}

\begin{abstract}
Biliary atresia (BA) is a childhood disease which manifests with abnormal narrowing, blockage or complete absence of bile ducts within the liver. Many possible etiologies have been reported for the development of $\mathrm{BA}$, including congenital, perinatal and acquired conditions. Since the 1970's, there has been increasing evidence linking BA development to viral perinatal infections. The viral vectors most commonly implicated include members of the herpesviridae family (cytomegalovirus and Epstein-Barr virus) as well as those of the reoviridae family (reovirus and rotavirus). While extensive work has been done on a murine model of disease, the current review focuses primarily on evidence from human studies of viral vectors in children afflicted with $B A$.
\end{abstract}

Citation of this article: Averbukh LD, Wu GY. Evidence for viral induction of biliary atresia: A review. J Clin Transl Hepatol 2018;6(4):410-419. doi: 10.14218/JCTH.2018.00046.

\section{Introduction}

Biliary atresia (BA) is a childhood disease which manifests with abnormal narrowing, blockage or complete absence of bile ducts within the liver. This condition can lead to neonatal cholestasis by the progressive fibrosis and inflammation of both intrahepatic and extrahepatic bile ducts. Patients with BA and subsequent cholestasis often experience jaundice, pruritus, pale stools, dark urine and poor growth, with eventual progression towards cirrhosis, portal hypertension and eventually decompensated liver failure. The symptoms of BA are initially indistinguishable from other causes of neonatal jaundice. However, unlike physiological causes, the symptoms of BA continue to worsen 2 weeks after birth. ${ }^{1}$ Fortunately, BA, unlike other causes of jaundice, does not lead to kernicterus as conjugated, rather than unconjugated, bilirubin is elevated. ${ }^{2}$

BA is found worldwide, although incidence rates differranging from 1 in every 12,000 live births in the USA to a high of 1 in every 3,000 live births in East Asia. ${ }^{1,3}$ The disorder appears to have a slight female preponderance, and by

Keywords: Biliary atresia; Cytomegalovirus; Epstein-Barr virus; Reovirus; Rotavirus.

Abbreviations: BA, biliary atresia; CMV, cytomegalovirus; EBV, Epstein-Barr virus; IFN $\gamma$, interferon gamma; Ig, immunoglobulin; IL, interleukin; NK, natural killer; Pp65, CMV immunodominant phosphoprotein 65; Th, T helper cell; TLR, toll-like receptors; TNF $\alpha$, tumor necrosis factor $\alpha$; TRAIL, TNF-related apoptosisinducing ligand; Treg, $T$ regulatory cell.

Received: 29 July 2018; Revised: 5 September 2018; Accepted: 7 September 2018

*Correspondence to: Leon D. Averbukh, Department of Medicine, Division of Gastroenterology-Hepatology, University of Connecticut Health Center, 236 Farmington Ave., Farmington, CT 06030, USA. Tel: +1-347-306-4752, E-mail: averbukh@uchc.edu current estimates only $15-20 \%$ of children with BA reach adulthood without requiring a liver transplant. For those children that are fortunate enough to not require liver transplant by adulthood, over $95 \%$ have evidence of chronic liver disease and cirrhosis. ${ }^{1}$

Work-up for suspicion of BA is extensive. Once blood, urine and stool samples are obtained, abdominal ultrasound is used to exclude other potential causes. Further work-up includes hepatobiliary scintigraphy to check for patency of the extrahepatic biliary tree and liver biopsy to look for characteristic features of BA, which include expanded portal tracts with bile duct proliferation, fibrosis and inflammation, portal tract edema, and numerous bile plugs. It is worth noting, however, that the earliest histologic changes seen in BA are nonspecific, and a liver biopsy done in the very early stages of the disease process may lead to false negative results. ${ }^{4}$ The current gold standard for the diagnosis of BA is intraoperative cholangiogram, though as the name suggests it is usually reserved for late stages of disease prior to surgery.

Treatment of BA revolves around the Kasai procedure. First introduced in the 1950's, a Roux en Y loop of bowel is created and anastomosed to the hilum of the liver. ${ }^{5}$ This is done to enable the remaining small patent bile ducts to drain. Unfortunately, $50 \%$ of those that undergo the procedure will require liver transplant by the age of 2 years. ${ }^{6}$ For all patients that undergo the Kasai procedure there is a significant increased risk of cholangitis secondary to the bacterial stasis that occurs from the anatomical placement of the Roux limb. ${ }^{7}$ For those that undergo liver transplant, studies have shown 10-year survival rate percentages in the low to mid 80 's overall and 10-year graft survival rate percentages in the low 70's. ${ }^{8,9}$ One study found on subsequent post-transplant liver biopsies that histology was abnormal in $73 \%$ of longterm survivors, although the pathology was consistent with chronic rejection and centri-lobular fibrosis rather than recurrent biliary atresia. ${ }^{8}$

Many etiologies have been proposed for the development of BA. Most cases ( $80 \%)$ are considered perinatal or acquired, while a minority are congenital. ${ }^{1}$ For perinatal/acquired cases of $B A$, reported etiologies have included autoimmune diseases, such as graft vs host disease, passed from mother to child and toxins, such as aflatoxin in genetically susceptible populations. ${ }^{10,11}$

In 1974 it was first suggested that cholestatic changes in infants may be due to virus-induced liver damage. ${ }^{12}$ The two commonly implicated viral families in relation to BA have been the herpesviridae and reoviridae. Animal models have provided direct evidence supporting viral involvement; in particular, cytomegalovirus (CMV) injection into guinea pigs was shown to cause inflammatory injury to bile duct epithelia similar to that seen in humans and reovirus injection has shown similar results in the murine model. ${ }^{13,14}$ However, 
because of species differences, the data derived from animal models cannot be completely representative of the human situation. Therefore, the aim of this review was to select studies from 1990 to present with clinical data on human subjects with $B A$ in order to critically examine the correlation found between CMV, Epstein-Barr virus (EBV), reovirus and rotavirus and the development of BA.

\section{CMV}

CMV, also known as human cytomegalovirus and human herpes virus-5, is a double-stranded (ds)DNA virus of the herpesviridae family, with an age-dependent seroprevalence estimated to be $60-70 \%$ in industrialized nations, and close to $100 \%$ in developing ones. ${ }^{15}$ While infection is not life threatening, and may even go unnoticed in healthy adults, it can be life threatening to those that are immunocompromised, recipients of organ transplants, or newborns. The congenital form of infection presents with a constellation of symptoms, characterized by hearing loss, petechiae, jaundice, developmental and motor delay, periventricular calcification, vision loss, microcephaly, and seizures. CMV may pass through the bodily fluids, including saliva, blood, urine, semen and breastmilk. ${ }^{16-18}$

Congenital CMV infection rates are estimated to range from $1-5 \%$ in areas of high seroprevalence and 0.4 to $2 \%$ in areas of low seroprevalence. ${ }^{19}$ However, not all neonates with CMV are cases of congenital infection. Preterm infants and those that are immunocompromised are particularly susceptible to postnatal infection. ${ }^{20}$ The diagnosis of postnatal CMV is generally obtained by urine testing, along with PCR or culture, and done within the first 3 weeks of life in order to differentiate postnatal infection from the congenital variant. ${ }^{21}$ CMV infection in normal term infants, when symptomatic, usually presents with transient fever, mild pneumonitis, vomiting, diarrhea, hepatitis, and abnormal blood counts. For those that have liver involvement, liver function tests usually improve by 2 to 3 months. ${ }^{22}$

Efficacy of CMV infection treatment in neonates remains inconclusive, with some evidence from case reports and series showing possible improved outcomes with the antiviral agents ganciclovir and valganciclovir. ${ }^{23-25} \mathrm{CMV}$ is by far the most studied virus in humans in its relationship to BA, although the results of these studies have been mixed and inconclusive. ${ }^{13,14,21,26-37}$

While some studies used antibody positivity and PCR/CMV immune-dominant phosphoprotein 65 (pp65) positivity on biopsy, for the intents of this review, all patients who were only CMV immunoglobulin (Ig)M+ were categorized together with those that were also/only $\mathrm{PCR}+/ \mathrm{pp} 65+$. This was done because IgM positivity may indicate acute or persistent infection, and $\mathrm{PCR} / \mathrm{pp} 65$ values are not likely to be false negatives. Further, as symptoms of BA are noted in late stages, IgM positivity in the setting of PCR/pp65 negativity may mean that the patient had a recent infection which has subsequently cleared. This could still indicate that the infection was involved in the pathogenic process. However, we did not include those patients who were only CMV IgG+ in the CMV+ category, as IgG has been found to be maternally acquired and can linger in infant serum for up to 8 months. ${ }^{38}$ Coincidentally, this was within the time frame from which most laboratory test samples and biopsies were taken.

As seen in Table 1, the rates of reported CMV+ neonates with $\mathrm{BA}$ varied, ranging from $0 \%$ to $76.9 \%$. Overall, the findings of these studies were inconclusive. Of the six papers that reported an association between CMV infection and cholestatic disorders, only three supported a link between a viral infection and pure BA. ${ }^{14,21,33}$ Others found no evidence of a link between CMV infection as an etiology for either cholestatic disease or BA. ${ }^{27,30,36}$

Unfortunately, there was a lack of consistency in experimental design amongst current investigations into the correlation between CMV infection in infancy and development of BA. Of the studies listed in Table 1 , six of the fifteen did not include a control group. ${ }^{14,21,30-33,35-37}$ This is problematic, as CMV prevalence varies by region. For those studies that did have control groups, the patients that made up these control groups varied from healthy infants to those with non-BA associated liver disease. While it would be unethical to obtain liver biopsy from healthy infants for control group PCR, the question remains as to whether a control population consisting of patients with various disorders involving liver disease may themselves have an increased susceptibility for CMV infection.

Due to the young age of the population pools used in the analysis of CMV incidence in BA and neonatal cholestasis, it is important to discern whether the patients had liver disease with associated BA in the setting of congenital CMV infection or if they acquired the infection perinatally and subsequently developed pathology. As seen in Table 1, most of the studies did not check the infants for CMV within the first 3 weeks of life, when they are most likely to be confirmed to have the congenital variant. ${ }^{26}$ Two studies did investigate maternal CMV seropositivity and found that neonatal rates of infection were significantly higher than those of their mothers, indicating that most CMV infections in infants were likely perinatal. ${ }^{34,39}$ Two studies did explore trends in the experimental and control population pools and found a significant difference in age between those patients who were CMV+ and CMV- and underwent a Kasai procedure. Those who were CMV+ were on average 13 to 15 days older. ${ }^{21,32}$ This supports the idea that the cause of BA was less likely to be genetic/congenital, and more likely secondary to an acquired perinatal infection in $\mathrm{CMV}+$ patients.

Another study found other differences between BA patients undergoing Kasai based on their CMV status. ${ }^{21}$ $\mathrm{CMV}+$ patients had significantly higher total bilirubin, lower platelet counts, longer resolution of jaundice post-Kasai procedure, and worse aspartate aminotransferase to platelet ratio index as an indicator of liver fibrosis. Liver ultrasound also showed greater spleen size and higher degrees of inflammation and fibrosis compared to BA patients who were CMV-. The CMV- patients had higher degrees of lobular cholestasis, with no significant difference in ductular cholestasis. ${ }^{26}$

Delayed jaundice resolution post-Kasai procedure was also found in another study in patients with "active" CMV infections (defined as pp65+ patients), although the researchers did not find a statistical significance in jaundice resolution rates in patients labeled as CMV "+" (defined as those who were CMV IgM+ and/or IgG+, but pp65-). ${ }^{34}$ The addition of purely IgG+ infants into the CMV+ group may be the source of discrepancy for the statistical significance since IgG positivity in infants is not proof of an active or even past infection until around 8 months of age, as previously mentioned.

In those patients who had "active" CMV infection (pp65+ $+/-$ IgM+), the rates of cholangitis following the Kasai procedure were significantly higher, hyperplasia of bile canaliculi was more extensive, and inflammatory zones were wider than for those that were CMV- or + (IgM+ and/or IgG+ W/ pp65-). ${ }^{33}$ 


\begin{tabular}{|c|c|c|c|}
\hline First author ${ }^{R E F}$ & $\begin{array}{l}\text { Numbers of } \\
\text { BA cases; } \\
\text { Demographics } \\
\text { at study time }\end{array}$ & Testing method; sample type & $\begin{array}{l}\text { Results in BA group and control group, } \\
\text { if provided }\end{array}$ \\
\hline Chang $^{13}$ & $\begin{array}{l}26 ; 0.7-5 \text { months } \\
\text { age range, } 2.1 \\
\text { months avg. age }\end{array}$ & $\begin{array}{l}\text { PCR for immediate early gene } 1 \& 2(\mathrm{~L}) \\
\text { Antibody assay }(\mathrm{S} \& \mathrm{U})\end{array}$ & $\begin{array}{l}\text { BA: } 2 / 26 \text { PCR+ }(7.6 \%) \text { [unknown } \\
\text { serology/ urine results for only BA vs } \\
\text { neonatal hepatitis patients]; Control: } \\
\text { 0/30 PCR }(0 \%)\end{array}$ \\
\hline De Tomasso 26 & $\begin{array}{l}32 ; 25-239 \text { days, } \\
82.5 \text { days avg. age }\end{array}$ & Nested PCR (L \& PH); Antibody assay (S) & $\begin{array}{l}\text { BA: } 20 / 32 \text { PCR+ and/or IgM+ }(62.5 \%) ; \\
\text { Control: } 0 / 9(0 \%) \text { only PCR provided }\end{array}$ \\
\hline $\begin{array}{l}\text { Domiati } \\
\text { Saad }^{27}\end{array}$ & $\begin{array}{l}9 ; 1 \text { month to } 4 \\
\text { years, } 12 \text { months } \\
\text { avg. age }\end{array}$ & PCR (L); Histological assessment (L) & BA: $1 / 9(11.1 \%)$; Control: 0/8 (0\%) \\
\hline Fischler $^{28}$ & $\begin{array}{l}21 ; 1-21 \text { weeks } \\
\text { (all patients), } 8 \\
\text { weeks avg. age (all } \\
\text { patients) }\end{array}$ & $\begin{array}{l}\text { Nested PCR for major immediate-early } \\
\text { gene (L); Antibody assay (S \& U) }\end{array}$ & $\begin{array}{l}\text { BA: } 12 / 21 \text { PCR+ and/or IgM+/U+ } \\
(57 \%) ; \text { Control: } 2 / 35 \mathrm{IgM}+(5.7 \%) \\
\text { [though } 4 \text { later had increasing IgG } \\
\text { signifying positive serology] }\end{array}$ \\
\hline Fjaer $^{29}$ & $\begin{array}{l}10 ; 48-102 \text { days, } \\
74 \text { days avg. age }\end{array}$ & $\begin{array}{l}\text { RT-PCR for glycoprotein B (L \& U); Viral } \\
\text { culture (U)/ Antibody assay (S)/ } \\
\text { Immune peroxidase technique pp65 in } \\
\text { leukocytes (S) }\end{array}$ & BA: $4 / 10(40 \%)$; Control: 0/10 (0\%) \\
\hline Jevon 30 & $\begin{array}{l}12 ; 44-200 \text { days, } \\
86 \text { days avg. age }\end{array}$ & PCR (L); In situ hybridization (L) & BA: $0 / 12(0 \%)$ \\
\hline Lazim $^{31}$ & $\begin{array}{l}\text { 13; Demographics } \\
\text { unknown }\end{array}$ & $\begin{array}{l}\text { Immunohistochemistry for CMV protein } \\
\text { pp65 (L) }\end{array}$ & BA: $10 / 13(76.9 \%)$ \\
\hline Rauschenfels ${ }^{32}$ & $\begin{array}{l}74 ; 19-149 \text { days, } \\
56 \text { avg. age }\end{array}$ & RT-PCR for polymerase gene (L) & BA: $8 / 74(10.8 \%)$ \\
\hline Soomro 33 & $\begin{array}{l}33 ; 1.0-5.0 \\
\text { months, } 2.5 \\
\text { months avg. age }\end{array}$ & PCR (S); Antibody assay (S) & BA: $14 / 33(42.4 \%)$ \\
\hline Shen ${ }^{34}$ & $\begin{array}{l}27 ; 14-28 \text { days, } 19 \\
\text { days avg. age }\end{array}$ & $\begin{array}{l}\text { Immunocytochemical detection of } \\
\text { CMV-pp65 antigenemia assay (PH \& L); } \\
\text { Antibody assay (S) }\end{array}$ & $\begin{array}{l}\text { BA: } 15 / 27 \text { pp } 65+(55.6 \%) \text { [Unable to } \\
\text { determine IgM positivity alone, as } \\
\text { clustered with IgG results] }\end{array}$ \\
\hline $\operatorname{Tarr}^{35}$ & $\begin{array}{l}23 ; 10-124 \text { days, } \\
61 \text { days avg. age }\end{array}$ & $\begin{array}{l}\text { Antibody assay }(S) \text {; Viral culture } \\
(L, U, S)\end{array}$ & BA: $5 / 23(21.7 \%)$ \\
\hline$X u^{14}$ & $\begin{array}{l}85 ; 12-180 \text { days, } \\
56 \text { days avg. age }\end{array}$ & $\begin{array}{l}\text { PCR (L); Immunocytochemical detection } \\
\text { of CMV-pp65 antigenemia assay (L) }\end{array}$ & BA: $51 / 85(60 \%)$ \\
\hline Yaghobi $^{36}$ & $\begin{array}{l}34 ; 20-70 \text { days, } 44 \\
\text { days avg. age }\end{array}$ & $\begin{array}{l}\text { Nested-PCR for UL55 gene (L); Antigenic } \\
\text { assay (L) }\end{array}$ & BA: $0 / 34(0 \%)$ \\
\hline Zani $^{21}$ & $\begin{array}{l}210 ; 44-141 \text { days, } \\
70 \text { days avg. age }\end{array}$ & $\begin{array}{l}\text { Immunohistochemistry with antibody } \\
\text { against } C M V(L, B R)\end{array}$ & BA: $20 / 210(9.5 \%)$ \\
\hline $\begin{array}{l}\text { Zabiegaj- } \\
\text { Zwick }^{37}\end{array}$ & $\begin{array}{l}\text { 27; Demographics } \\
\text { unknown }\end{array}$ & Antibody assay (S) & $\begin{array}{l}\text { BA: } 20 / 27(74 \%) \text {; Control: } 8 / 34 \\
(23.5 \%)\end{array}$ \\
\hline
\end{tabular}

Abbreviations: BA, biliary atresia; BR, biliary remnant; L, liver; PCR, polymerase chain reaction; $\mathrm{PH}$, porta hepatis; $\mathrm{S}$, serum; $\mathrm{U}$, urine.

Again, the lack of significance in the CMV+ group could be due to the method of including patients who were solely IgG+ as $\mathrm{CMV}+$.

\section{EBV}

EBV is also a member of the herpesviridae family and is best known as the cause of infectious mononucleosis. Although symptoms closely mimic those of CMV in adolescents and adults, it is differentiated by the finding of heterophile antibody. There is also some evidence that EBV may be responsible for the development of such autoimmune disorders as Sjogren's, rheumatoid arthritis, and systemic lupus erythematosus. ${ }^{39,40}$ EBV remains a highly prevalent virus, with an estimated $82.9 \%$ of $18-19$ year-olds in the USA displaying seroprevalence. ${ }^{41} \mathrm{EBV}$ is commonly acquired during childhood years, with resulting infections more likely to be asymptomatic than when infected as an adult.

Intrauterine infection with EBV is rare because fewer than $5 \%$ of pregnant women are susceptible (seronegative) to the virus. ${ }^{42}$ While isolated cases of infants with some evidence for EBV infection and congenital anomalies (congenital heart 
disease, hypotonia, micrognathia, cataracts and thrombocytopenia) have been reported, the evidence argues against EBV as a significant cause of congenital infection. ${ }^{43}$ Specifically, no evidence of EBV infection has been demonstrated in large studies of children with congenital anomalies or in umbilical cord blood samples. ${ }^{42}$ Prospective studies have not found evidence of congenital abnormalities among infants of women who did develop primary EBV infection during pregnancy. 42

As seen in Table 2, EBV has been much less studied than $\mathrm{CMV}$ in relation to the development of BA. Studies have shown weak evidence correlating EBV and $\mathrm{BA}$, although some case reports have claimed there is a connection. ${ }^{45,46}$ Current studies show rates of EBV infection in patients with BA ranging from $0 \%$ to a high of $40 \% \cdot{ }^{27,29}$ Two of the studies employed the use of a control group, both of which showed a seroprevalence of $0 \% \cdot{ }^{27,29}$ Only one study primarily investigated EBV seroprevalence in perinatal cases of BA rather than other viral vectors as well, and all but one study employed the use of PCR. ${ }^{44}$

As with the studies involving CMV, a lack of control groups across studies makes differences in EBV prevalence between

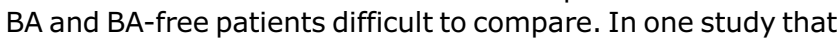
did provide a control group, a significant difference in EBV incidence was found. ${ }^{29}$ Though the study did use pretreatment of PCR products with uracil $\mathrm{N}$ glycosylase prior to amplification to avoid false positive PCR results, the significance of their findings may be questionable due to the small sample size.

In another study, which found a $12.5 \%$ EBV infection rate in the BA patient pool, EBV was detected within the biliary epithelium, suggesting that the virus is able to penetrate and reproduce there. ${ }^{47}$ However, this information alone does not prove that EBV is involved in the development of BA.

\section{Rotavirus}

Rotavirus, a dsRNA virus of the reoviridae family, is an extremely common cause of gastroenteritis in the unvaccinated, accounting for $90 \%$ of gastroenteritis cases worldwide. Most unvaccinated children experience infection and ensuing diarrheal illness by the age of 5 years. ${ }^{48}$ Of the nine species of rotavirus, named alphabetically A-I, rotavirus type A is believed to be the most common infectious variant in humans, although rotavirus type $B$ has been reported to cause adult gastroenteritis outbreaks. ${ }^{49}$ The virus is transmitted by the fecal-oral route and symptoms include vomiting, non-bloody diarrhea, and fever. Other associated manifestations of rotavirus infection, though rare, include necrotizing enterocolitis, encephalopathy, and seizures. ${ }^{50-52}$

As seen in Table 3, four studies investigated the possible correlation between rotavirus and BA. Rotavirus types A and C were the most commonly investigated, with one study failing to report the target serotype investigated. ${ }^{32}$ Three of the four studies used PCR, nested or seminested, in their investigations and targeted proteins VP3 (a methyltransferase mRNA capping enzyme), VP4 (part of rotavirus cell attachment and virulence), NSP1 (a 5'-RNA binding, interferon antagonist), VP6 (a structural and species-specific antigen), and VP7 (a structural and neutralization antigen). ${ }^{33,53,54}$ One of the papers relied purely on serum antibodies for determination of infectious state, while the rest used liver samples and, in some cases, feces (unclear how obtained) and bile remnants (Table 3).

Rates of rotavirus prevalence in $\mathrm{BA}$ were noted to range from $0 \%$ to $15 \%$ for rotavirus A and $40 \%$ for rotavirus C using the low cut-off provided for optical density values. ${ }^{54,55}$ It should be noted, however, that in one study, although rotavirus prevalence was high in the BA group, it was also high in the control group and the difference between them was found not reach the threshold for statistical significance. ${ }^{55}$ Another study showed significantly increased rates of rotavirus $C$ infection in BA patients, in comparison to control groups. ${ }^{56}$ However, the PCR products collected in that case were not sequenced and, as a result, the possibility of false positives cannot be excluded.

Unlike the other viruses reviewed, there is a vaccine against rotavirus, and its use can alter the incidence of infection rate and prevalence. However, two of the reviewed studies were done prior the availability of RotaShield ${ }^{\circledR} .54,56$ Of the remaining two studies, only one specified that the samples tested were obtained prior to the reintroduction of rotavirus vaccines in 2006.55 It is unclear whether or not the $0 \%$ seroprevalence in the other more recent study was affected by patient vaccination. ${ }^{32}$ Unfortunately, all of the studies had small sample sizes, further limiting the conclusions that can be drawn from them.

Another limiting factor seen in the present studies was the age of patients at the time of specimen procurement. In one of the papers, samples were obtained during liver transplant when the patient was 10 years-old. ${ }^{54}$ As this was a case of BA, the patient likely began developing the condition many years

Table 2. EBV incidence in BA

\begin{tabular}{|c|c|c|c|}
\hline First author ${ }^{\text {REF }}$ & $\begin{array}{l}\text { Numbers of BA cases; } \\
\text { Demographic }\end{array}$ & Testing method & $\begin{array}{l}\text { Results in BA group and control } \\
\text { group, if provided }\end{array}$ \\
\hline $\begin{array}{l}\text { Domiati- } \\
\text { Saad }^{27}\end{array}$ & $\begin{array}{l}9 ; 1 \text { month to } 4 \text { years, } 12 \\
\text { months avg. age }\end{array}$ & $\begin{array}{l}\text { PCR }(L) \text {; Histological } \\
\text { assessment }(L)\end{array}$ & BA: $0 / 9(0 \%)$; Control: 0/9 (0\%) \\
\hline Fjaer $^{29}$ & $\begin{array}{l}\text { 10; } 48-102 \text { days, } 74 \text { days } \\
\text { avg. age }\end{array}$ & $\begin{array}{l}\text { RT-PCR (L \& S); Antibody } \\
\text { assay (S) }\end{array}$ & $\begin{array}{l}\text { BA: } 4 / 10(40 \%) ; \text { Control: } \\
0 / 10(0 \%)\end{array}$ \\
\hline Mahjoub $^{44}$ & $\begin{array}{l}16 ; 36-152 \text { days, } 72 \text { days } \\
\text { avg. age }\end{array}$ & $\begin{array}{l}\text { Chromogenic in situ hybridization } \\
\text { (CISH) (L \& BE) }\end{array}$ & BA: $2 / 16(12.5 \%)$ \\
\hline Rauschenfels ${ }^{32}$ & $74 ; 19-149$ days, 56 avg. age & RT-PCR for BNRF-1 gene (L) & BA: $0 / 74(0 \%)$ \\
\hline$X u^{14}$ & $\begin{array}{l}85 ; 12-180 \text { days, } 56 \text { days } \\
\text { avg. age }\end{array}$ & RT-PCR (L) & BA: $3 / 85(3.5 \%)$ \\
\hline
\end{tabular}

Abbreviations: BA, biliary atresia; BE, biliary epithelium; BR, biliary remnant; L, liver; RT-PCR, reverse transcriptase-polymerase chain reaction; S, serum; U, urine. 


\begin{tabular}{|c|c|c|c|}
\hline First author ${ }^{R E F}$ & $\begin{array}{l}\text { Numbers of BA cases; } \\
\text { Demographic }\end{array}$ & Testing method & $\begin{array}{l}\text { Results in BA group and } \\
\text { control group, if provided }\end{array}$ \\
\hline Bobo $^{54}$ & $\begin{array}{l}10 ; 1 \text { month to } 10 \text { years, } \\
18 \text { months avg. age }\end{array}$ & $\begin{array}{l}\text { Nested PCR for genes } 3 \text { (Rota B) \& } 6 \text { (Rota } \\
A, C) ; \text { Southern blot of } L \text { and BR }\end{array}$ & $\begin{array}{l}\text { BA: } 0 / 10(0 \%) ; \text { Control: } \\
0 / 14(0 \%)\end{array}$ \\
\hline Clemente ${ }^{55}$ & $\begin{array}{l}40 ; 4.7-13 \text { weeks, } 62 \text { days avg. } \\
\text { age }\end{array}$ & Antibody assay for Rota A and Rota C (S) & $\begin{array}{l}\text { BA: IgM+; Rota A, 4-16/ } \\
40(10-40 \%) ; \text { Rota C, 0- } \\
6 / 40(0-15 \%) \\
\text { Control: IgM+; Rota A, } \\
\text { 7-14/38 (18-37\%); Rota } \\
\text { C, } 1-9 / 38(3-24 \%)\end{array}$ \\
\hline Rauschenfels ${ }^{32}$ & $\begin{array}{l}64 \text {; Unknown, patient } \\
\text { information provided for total } \\
\text { group of } 74 \text { (see above) }\end{array}$ & $\begin{array}{l}\text { RT-PCR for gene } 4 \text { (Rota type not } \\
\text { mentioned) (L) }\end{array}$ & BA: $0 / 64(0 \%)$ \\
\hline $\begin{array}{l}\text { Riepenhoff- } \\
\text { Talty }{ }^{56}\end{array}$ & $\begin{array}{l}18 ; 24-103 \text { months, } 41.7 \\
\text { months avg. age. }\end{array}$ & $\begin{array}{l}\text { Seminested PCR for gene } 9(\text { Rota A); } \\
\text { Nested PCR for genes } 5 \& 6 \text { (Rota C) (RNA } \\
\text { from F or L or BS) }\end{array}$ & $\begin{array}{l}\text { BA: Rota A, 0/12 (0\%); } \\
\text { Rota C, } 10 / 20(50 \%) \\
\text { Control: } 0 / 12(0 \%)\end{array}$ \\
\hline
\end{tabular}

Abbreviations: BA, biliary atresia; BE, biliary epithelium; BR, biliary remnant; L, liver; RT-PCR, reverse transcriptase-polymerase chain reaction; S, serum; Rota, rotavirus; U, urine.

prior and any inciting viral vector, such as rotavirus-based on the mixed viral/inflammatory disease model for BA development as described later in this review-would likely have long resolved by the time of PCR analysis.

The murine model has shown that the strains of rotavirus thought most likely to contribute to BA development attach to integrin $\alpha 2 \beta 1$ receptors found on cholangiocytes, but not on hepatocytes. ${ }^{57,58}$ This may mean that testing biliary epithelium and bile might be an additional means of detection. Use of PCR on liver biopsy specimens may lead to false positives as well, as the strains responsible for liver disease may not be the same ones that promote cholangiocyte infection and subsequent BA.

Additionally, antibody testing, rather than PCR, provides similar issues to those seen with the other viral vectors discussed in this review. IgG antibodies for rotavirus are not useful indicators of history of infection because for the first 4-6 months of life, children have IgG antibodies for rotavirus acquired transplacentally from their mothers. ${ }^{59}$ IgM antibodies may themselves be too transient to be of regular use on evaluation in BA. Hertel et al. ${ }^{59}$ proposed, instead, the use of IgA antibodies in children younger than the age of 2 months (before the administration of rotavirus vaccination), as it can detect primary infections in children, persists for several months, and is not affected by existing maternal antibody.

There are also potential pitfalls in the use of PCR, which can compromise results. There is significant sequence diversity amongst rotavirus strains for the same proteins. ${ }^{60}$ This may mean that primer specificity is important for optimal detection of specific viral strains.

\section{Reovirus}

Unlike the other viruses investigated in this review, reovirus, also a member of the reoviridae family, has no pathology associated with infections. However, its viral particles have been identified in the liver of neonates with biliary atresia. ${ }^{61}$ Reovirus, especially serotype 3 , has been particularly studied in the murine model for its role in producing disease with similar pathological features to human BA, such as necrosis of bile duct epithelium and inflammatory infiltrate. ${ }^{62,63}$ Interestingly, the murine model has shown ductal changes long after viral antigens are no longer detected. ${ }^{63}$ While work on closer human relatives, such as infant monkeys, has shown disease processes resembling human BA with reovirus infection, human studies have failed to consistently demonstrate a correlation between reovirus and BA development. ${ }^{64}$

Of the five studies examined, rates of seroprevalence of reovirus in patients with $\mathrm{BA}$ were noted to range from $0 \%$ to $55 \% .{ }^{65,67}$ Although most of the studies did have control groups, as with the other viral vectors, sample sizes were relatively low. As seen in Table 4, four of the papers used highly sensitive nested PCR, while one used seminested PCR. Of the four papers that used nested PCR, only two of them described employment of appropriate controls and sensitivities to maximize accuracy. ${ }^{65,67}$ One of the papers-with the highest detection rate of reovirus at $55 \%$ in those with BA-did not amplify products of their PCR, making it more difficult to confirm that the PCR products did not contain false positives. ${ }^{67}$ Unfortunately, two of the papers did not provide demographic information for their patient pools; although, an analysis of age distribution in one of them showed that patients with BA that were reovirus+ at the time of Kasai procedure were older (by an average of 6 days) when compared to the control group. ${ }^{32,56}$ An additional variable that cannot be excluded is the prospect that the reovirus infection could simply be a coincidental infection. ${ }^{32}$

The reviewed studies used different gene targets for PCR (Table 4). Three studies used genes coding for inner capsid protein components ( $\mathrm{L} 1$ and L3) involved in transcription and genome replication. One study used the M3 gene, which codes for microtubule-associated protein and is thought to be involved in the formation of viral inclusions; another study used the S3 gene, which codes for an outer capsid protein that is thought to be involved in genome packaging. ${ }^{68-71}$ The use of different gene targets introduces variability from genetic diversity, making primer selection and, thus, exclusion of false negatives more difficult. This in turn may be a reason for varying/low rates of reovirus detection. However, the L1and L3 genes appear to be highly conserved across reoviral strains and S3 appears to have high 
Averbukh L.D. et al: Viral biliary atresia: A review

Table 4. Reovirus incidence in BA

\begin{tabular}{|c|c|c|c|}
\hline First author ${ }^{R E F}$ & Numbers of BA cases; Demographics & $\begin{array}{l}\text { Testing method (sample } \\
\text { used) }\end{array}$ & $\begin{array}{l}\text { Results in BA group and } \\
\text { control group, if provided }\end{array}$ \\
\hline Rauschenfels $^{32}$ & $\begin{array}{l}\text { 64; Unknown, patient information provided } \\
\text { for total group of } 74 \text { (see Table } 3 \text { ) }\end{array}$ & $\begin{array}{l}\text { Nested RT-PCR for } L 3 \\
\text { gene }(L)\end{array}$ & BA: $21 / 64(32.8 \%)$ \\
\hline $\begin{array}{l}\text { Riepenhoff- } \\
\text { Talty }{ }^{56}\end{array}$ & $\begin{array}{l}\text { 9; Unknown, patient information provided for } \\
\text { total group of } 18 \text { (see Table 3) }\end{array}$ & $\begin{array}{l}\text { Seminested PCR for S3 } \\
\text { gene }(L, B S, F)\end{array}$ & $\begin{array}{l}\text { BA: } 0 / 9(0 \%) \text {; Control: } 0 / 2 \\
(0 \%)\end{array}$ \\
\hline Saito ${ }^{65}$ & $26 ; 0.7-46.6$ months, 12.7 months avg. age & $\begin{array}{l}\text { Nested } P C R \text { for } L 3 \text { gene } \\
(L, G B, P H \text { and } C B D)\end{array}$ & $\begin{array}{l}\text { BA: } 0 / 26(0 \%) \text {; Control 0/13 } \\
(0 \%)\end{array}$ \\
\hline Steele ${ }^{66}$ & $14 ; 3$ weeks to 3.5 months, N/A avg. age & $\begin{array}{l}\text { Nested PCR for M3 } \\
\text { gene }(L)\end{array}$ & $\begin{array}{l}\text { BA: } 0 / 14(0 \%) \text {; Control: } \\
0 / 17(0 \%)\end{array}$ \\
\hline Tyler $^{67}$ & $20 ; 1.5-6$ months, 2 months avg. age & $\begin{array}{l}\text { Nested PCR for L1 gene } \\
(L \& B D)\end{array}$ & $\begin{array}{l}\text { BA: } 11 / 20(55 \%) \text {; Control: } \\
7 / 33(21 \%)\end{array}$ \\
\hline
\end{tabular}

Abbreviations: BA, biliary atresia; BD, bile duct; BS, biliary suspension; CBD, common bile duct; F, fecal matter; GB, gallbladder; L, liver; PH, porta hepatis; RT-PCR, reverse transcriptase-polymerase chain reaction; $S$, serum; $U$, urine.

conservation at the $5^{\prime}$ - and $3^{\prime}$-ends, making them good targets for PCR primer development. ${ }^{65,72}$ The M3 gene, on the other hand, appears to be the third most divergent gene amongst strains (after S1 and M1), making primer design for PCR more complicated and more likely to have a lower yield. ${ }^{73}$

\section{Potential mechanisms by which viral vectors cause} biliary atresia

Many of the viruses discussed above have been shown to have varying degrees of association with the presence of BA. However, these viruses usually cause infections that do not lead to the development of BA. Therefore, a major focus of study in the viral pathogenesis of BA is the identification of peculiar responses of the host that predispose certain individuals to develop the disease.

\section{Innate immune pathway}

The innate immune system, in contrast to the adaptive immune system, is present in humans from birth and is not learned or permanently heightened after exposure to specific pathogens. While the adaptive immune system takes anywhere from days to weeks to respond to pathogens, the innate immune system responds immediately once pathogenic particles are recognized by pattern recognition receptors on leukocytes. The actions of the innate immune system are believed to be the first step in the development of virus-induced immune destruction of biliary epithelium. It has been shown that infection of biliary epithelium by viral vectors triggers release of proinflammatory cytokines, including tumor necrosis factor $\alpha$ (TNF $\alpha$ ), interleukin (IL)-1, and IL-6. Macrophages, natural killer (NK) cells, neutrophils, and dendritic cells respond to the infection. ${ }^{74}$

These cells all contain Toll-like receptors (TLRs), each one of which recognizes a specific pathogen-associated molecular pattern displayed on infected or necrotic biliary epithelial cells. ${ }^{75}$ Failure to properly regulate TLR signaling is believed to play a significant role in the development of chronic inflammatory disease. In BA specifically, TLRs 3, 7, and 8 have been noted to be highly up-regulated (Fig. 1). ${ }^{76}$ TLR3, when activated by viral dsRNA, results in biliary apoptosis by a TNF-related apoptosis-inducing ligand (commonly known as TRAIL). TLR7, on the other hand, was activated by viral single-stranded RNA and leads to increased levels of the signaling molecule human myxovirus resistance protein 1 and subsequent activation of type 1 interferons.

Macrophages cause significant biliary epithelial damage by TNF $\alpha$ production, as part of the innate immune system. CD14 is a macrophage cell surface glycoprotein that both recognizes endotoxin and activates TNF $\alpha$ release from macrophages. ${ }^{74}$ Individuals that possess $\mathrm{T} / \mathrm{T}$ homozygosity in the CD14 promoter region may have an increased risk of developing macrophage-induced biliary damage. A second polymorphism, located in the promoter region of the migration inhibitory factor, a macrophage and lymphocyte proinflammatory cytokine, has been associated with exaggerated innate immune response that may increase likelihood of disease progression to BA and chronic inflammatory disease. ${ }^{77}$

NK cells have also been identified as exacerbators of disease processes. A murine BA model has shown that depletion of NK cells or blockade of their Nkg2d receptor immediately following birth results in an absence of jaundice in rotavirus-infected pups. ${ }^{78}$ Human studies have demonstrated that elevated levels of plasmacytoid dendritic cells which produce cytokine IL-15, an important factor for NK cell activation, results in bile duct epithelial-targeted injury. ${ }^{79}$ However, the role of NK cells in the development of human BA has been questioned, as murine studies have also suggested that NK cells in human newborns may be too immature to kill virus-infected cholangiocytes. ${ }^{80}$

\section{Adaptive pathway}

Unlike the innate immune system, the adaptive immune system involves immune responses that are stimulated based on repeated pathogen exposure by effector $\mathrm{T}$ cells. Effector $\mathrm{T}$ cells release cytokines which either directly, or through activation of other immune cells, cause cellular damage. There are two important $T$ cell responses that have been investigated and noted in BA, as follows: 1) $T$ helper (Th) 1 cells, which induce IL-2, interferon gamma (IFN $\gamma$ ) and TNF $\alpha$; and, 2) Th17 cells which induce IL-17. In the inflammatory setting, IL-18 (IFN- $\gamma$-inducing factor), a macrophagederived cytokine, together with IL-12, has been reported to promote Th1 cell differentiation and subsequent IFN $\gamma$ production, causing bile duct injury. ${ }^{74}$ The importance of IFN $\gamma$ was demonstrated in a murine model in which rotavirusinfected IFN $\gamma$ knockout mice showed resolution of cholestasis, 


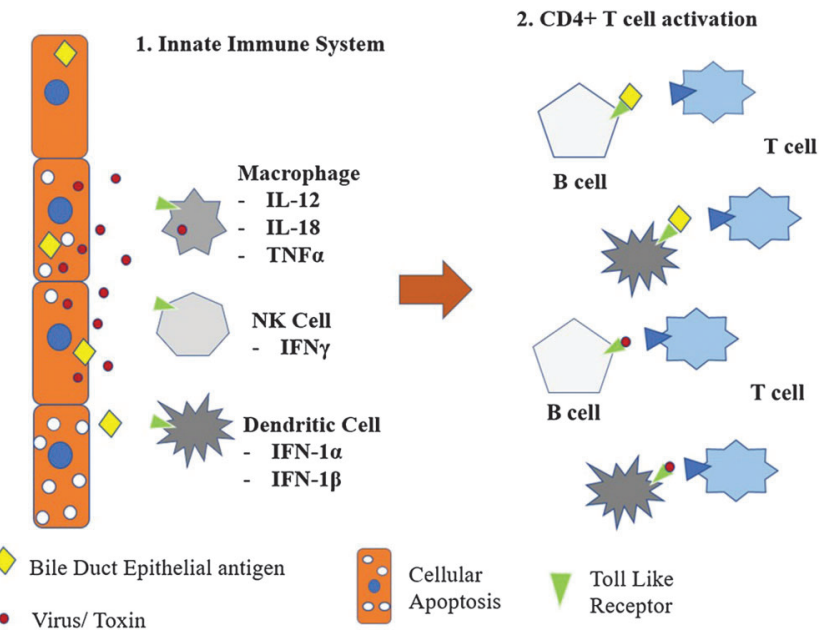

Fig. 1. Immunopathogenesis of biliary atresia. Viral infection of cholangiocytes leads to activation of the innate immune system and bystander damage. Toll-like receptor-pathogen-associated molecular pattern complexes subsequently lead to CD4+ activation for viral antigens as well as cross-reactive bile duct epithelial antigen.

while wild type rotavirus-infected mice showed biliary disease progression. ${ }^{81}$

Numbers of Th1 cells have been found to be elevated in CMV IgM+ cases of BA and, along with macrophages, are believed to be responsible for the degeneration of intrahepatic bile ducts. ${ }^{82}$ This supports the idea that while viral infection is important in the initiation of biliary disease, continued immunological response plays an important part in disease progression. The numbers of Th17 cells have been noted to be elevated in the portal tracts of BA patients and positively correlated to serum bilirubin levels. ${ }^{83}$ Additionally, IL-17 mRNA has been found to be significantly increased in BA patient tissues. ${ }^{84}$ However, unlike Th1 cells, elevated Th17 populations have not been correlated to infectious agents; therefore, they are considered to be more indicative of general inflammation and likely serve as a marker of severity and disease progression, rather than pathogenesis of BA.

$B$ cells-responsible for both antigen presentation and Ig production-have been implicated in playing a role in rotavirus-induced biliary disease with progression to BA. $\alpha$-Enolase-a glycolytic enzyme expressed in most tissues including biliary epithelium-has been shown to have an amino acid sequence similar to that of rotavirus-encoded proteins. ${ }^{85}$ Sera of human subjects with BA as well as that of rotavirus-infected mice have demonstrated the presence of $\alpha$-enolase antibodies. It has been shown that antirotavirus and antienolase antibodies cross-react with enolase and rotavirus proteins, making the chronic inflammation leading to $B A$ in the setting of infection a potential case of unfortunate molecular mimicry in susceptible individuals. ${ }^{85}$

\section{Immune dysregulation}

To determine the correlation between inflammatory response and disease development, murine models have examined the effect of age at the time of infection. Intraperitoneal rhesus rotavirus inoculation within the first 12 hours of birth has been shown to produce inflammatory reactions leading to extrahepatic and intrahepatic duct obliteration, similar to those seen

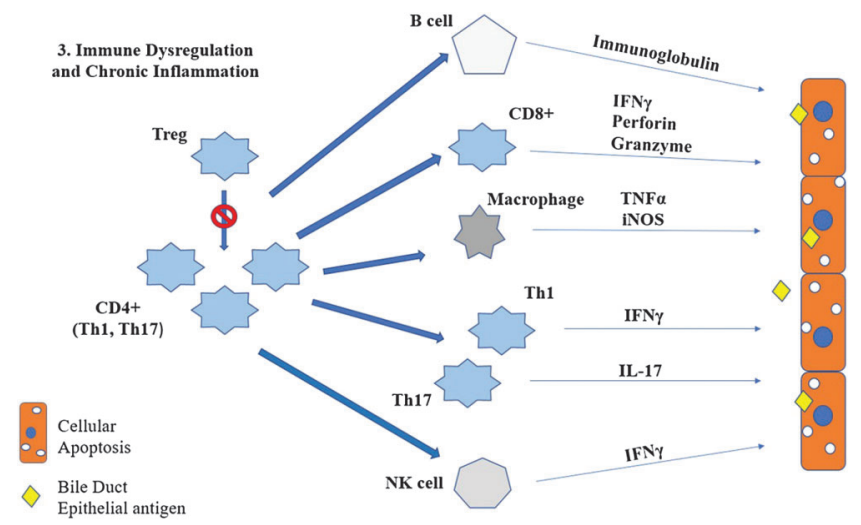

Fig. 2. Bystander damage of cholangiocytes and associated release of cross-reactive bile duct epithelial antigens induces autoreactive $\mathbf{T}$ cells. Depressed Treg numbers fail to regulate autoreactive T cells, leading to increased stimulation of downstream effector cells and resulting in chronic inflammation and continued biliary injury post-viral clearance.

Abbreviations: Treg, T regulatory cells.

in $B A .{ }^{83}$ One theory behind the progression of opportunistic infection leading to BA involves a deficiency of $T$ regulatory cells (Tregs). ${ }^{82}$ Infection with rhesus rotavirus, in the setting of low Treg numbers, has been shown to lead to up-regulation of NK and CD8+ cells, without proper suppression. ${ }^{79}$

The Treg subset of CD4+ cells is responsible for controlling $T$ cell-mediated immune responses to prevent "bystander damage" of healthy cells as well as activation of autoreactive T cells. Bystander damage refers to destruction of healthy cells near infected cells, secondary to either focused inflammatory cytokine release (such as TNF $\alpha$, TNF $\beta$, lymphotoxin, and nitric oxide) or direct destruction by CD4 cells, leading to additional immunopathology at sites of infection (Fig. 2). ${ }^{86}$ Studies in $\mathrm{CMV}+$ and rotavirus+ human children with BA have shown significantly decreased Treg numbers. ${ }^{87,88}$ The importance of Tregs in the prevention of progression of BA has been demonstrated in a murine model in which the addition of normal Tregs into rotavirus-infected neonatal mice decreased biliary duct inflammation and improved overall survival. ${ }^{74}$

Investigations into the cause of decreased Treg numbers have shown a possible role for epigenetic modifications by mechanisms that remain unclear at present. DNA hypermethylation in BA-afflicted children has been shown to prevent Foxp3 protein-a Treg cell regulator-from binding to DNA, resulting in suppressed Treg function. ${ }^{89}$ DNA hypomethylation has also been implicated in autoimmune disease in which hypomethylation of the IFN $\gamma$ gene promoter region was associated with unregulated production of IFN $\gamma .{ }^{90}$

\section{Conclusions}

While animal models have shown promise in linking viral vectors to the development of BA, evidence from human studies remains less conclusive. However, data on CMV-the most heavily studied viral vector in relation to BA-provides the strongest support. There are several possible causes for the conflicting findings in human investigations. Unfortunately, current studies have low enrollment and limited population data due to the rarity of BA. Additionally, due to ethical considerations, liver biopsies cannot be taken from healthy controls and are instead obtained from infants with 
other medical conditions. This can falsely elevate the rate of viral infection among the control group, as their immunocompromised state increases risk for infection compared to healthy infants.

Similarly, there is an absence of uniform study methodology, as highlighted by the irregular use of control groups, differing tissue sample types, tissue preservation protocols, and molecular methods-ranging from antibody assays to PCR. A lack of control groups makes it difficult to compare infection rates, and the high variability of tissue types and molecular investigative methods results in unequal test sensitivities.

Another investigative hurdle is the delay between viral infection and the appearance of BA symptoms. Additionally, differentiating between congenital versus acquired forms of BA with certainty is made more difficult by delays in investigation. However, this pitfall has been partially overcome. Studies have shown later average age of BA onset in cases with positive viral markers of infection while testing negative for evidence of congenital infection. This lends credence to the idea that these are perinatal infections.

The development of a vaccine for rotavirus may provide a unique opportunity for correlation between viral infection and $B A$. With increased use of the vaccine, it will be interesting to note whether there are observable reductions in BA rates in endemic areas.

While much focus has been placed on CMV, EBV, rotavirus, and reovirus in the study of virally-induced $B A$, other members of their respective viral families have not received as much attention. It may be worthwhile to further expand investigations to cover a broader scope of viruses to strongly correlate viral infection with BA development and increase the scope of potential vectors. Additionally, future studies should expand their scope beyond single vector identification as viral coinfections may significantly increase the risks of BA when compared to single viral infection.

If viral vectors are related to the development of BA, then the promotion of progression from biliary damage to endstage BA is likely to be multifactorial, involving viral damage, genetic and epigenetic characteristics, and both the innate and adaptive immune systems. Further studies will be needed to elucidate all of the molecular players involved and their interactions, in order to create effective diagnostic, prognostic and therapeutic modalities.

\section{Acknowledgments}

The support of the Herman Lopata Chair in Hepatitis Research (to GYW) is gratefully acknowledged.

\section{Conflict of interest}

The authors have no conflict of interests related to this publication.

\section{Author contributions}

Wrote the manuscript (LDA), developed the idea for the article, and critically revised it (GYW).

\section{References}

[1] Kobayashi H, Stringer MD. Biliary atresia. Semin Neonatol 2003;8:383-391. doi: 10.1016/S1084-2756(03)00065-4.
[2] Harpavat S, Finegold MJ, Karpen SJ. Patients with biliary atresia have elevated direct/conjugated bilirubin levels shortly after birth. Pediatrics 2011; 128:e1428-e1433. doi: 10.1542/peds.2011-1869.

[3] Mack CL. The pathogenesis of biliary atresia: evidence for a virus-induced autoimmune disease. Semin Liver Dis 2007;27:233-242. doi: 10.1055/s2007-985068.

[4] Azar G, Beneck D, Lane B, Markowitz J, Daum F, Kahn E. Atypical morphologic presentation of biliary atresia and value of serial liver biopsies. J Pediatr Gastroenterol Nutr 2002;34:212-215. doi: 10.1097/00005176200202000-00020.

[5] Davenport M, Ure BM, Petersen C, Kobayashi H. Surgery for biliary atresia-is there a European consensus? Eur J Pediatr Surg 2007;17:180-183. doi: 10. 1055/s-2007-965147.

[6] Schreiber RA, Barker CC, Roberts EA, Martin SR, Alvarez F, Smith L, et al. Biliary atresia: the Canadian experience. J Pediatr 2007;151:659-665, 665. e1. doi: 10.1016/j.jpeds.2007.05.051.

[7] Oh M, Hobeldin M, Chen T, Thomas DW, Atkinson JB. The Kasai procedure in the treatment of biliary atresia. J Pediatr Surg 1995;30:1077-1080; discussion 1080-1081. doi: 10.1016/0022-3468(95)90345-3.

[8] Fouquet V, Alves A, Branchereau S, Grabar S, Debray D, Jacquemin E, et al. Long-term outcome of pediatric liver transplantation for biliary atresia: a 10-year follow-up in a single center. Liver Transpl 2005;11:152-160. doi: $10.1002 /$ It.20358.

[9] Hartley JL, Davenport M, Kelly DA. Biliary atresia. Lancet 2009;374:17041713. doi: 10.1016/S0140-6736(09)60946-6.

[10] Muraji T, Hosaka N, Irie N, Yoshida M, Imai Y, Tanaka K, et al. Maternal microchimerism in underlying pathogenesis of biliary atresia: quantification and phenotypes of maternal cells in the liver. Pediatrics 2008;121:517-521. doi: 10.1542/peds.2007-0568.

[11] Kotb MA. Aflatoxins in infants with extrahepatic biliary atresia. Med J Cairo Univ 2015;83:207-210.

[12] Landing BH. Considerations of the pathogenesis of neonatal hepatitis, biliary atresia and choledochal cyst-the concept of infantile obstructive cholangiopathy. Prog Pediatr Surg 1974;6:113-139.

[13] Chang MH, Huang HH, Huang ES, Kao CL, Hsu HY, Lee CY. Polymerase chain reaction to detect human cytomegalovirus in livers of infants with neonatal hepatitis. Gastroenterology 1992;103:1022-1025. doi: 10.1016/00165085(92)90038-Z.

[14] Xu Y, Yu J, Zhang R, Yin Y, Ye J, Tan L, et al. The perinatal infection of cytomegalovirus is an important etiology for biliary atresia in China. Clin Pediatr (Phila) 2012;51:109-113. doi: 10.1177/0009922811406264.

[15] Wang W, Zheng S, Shong Z, Zhao R. Development of a guinea pig model of perinatal cytomegalovirus-induced hepatobiliary injury. Fetal Pediatr Pathol 2011;30:301-311. doi: 10.3109/15513815.2011.572959.

[16] Jordan MC, Rousseau WE, Noble GR, Steward JA, Chin TD. Association of cervical cytomegaloviruses with venereal disease. N Engl J Med 1973;288: 932-934. doi: 10.1056/NEJM197305032881803.

[17] Ko JH, Peck KR, Lee WJ, Lee JY, Cho SY, Ha YE, et al. Clinical presentation and risk factors for cytomegalovirus colitis in immunocompetent adult patients. Clin Infect Dis 2015;60:e20-e26. doi: $10.1093 / \mathrm{cid} /$ ciu969.

[18] Lawrence RM. Cytomegalovirus in human breast milk: risk to the premature infant. Breastfeed Med 2006;1:99-107. doi: 10.1089/bfm.2006.1.99.

[19] Manicklal S, Emery VC, Lazzarotto T, Boppana SB, Gupta RK. The "silent" global burden of congenital cytomegalovirus. Clin Microbiol Rev 2013;26: 86-102. doi: 10.1128/CMR.00062-12.

[20] Kurath S, Halwachs-Baumann G, Müller W, Resch B. Transmission of cytomegalovirus via breast milk to the prematurely born infant: a systematic review. Clin Microbiol Infect 2010;16:1172-1178. doi: 10.1111/j.14690691.2010.03140.x.

[21] Zani A, Quaglia A, Hadzić N, Zuckerman M, Davenport M. Cytomegalovirusassociated biliary atresia: An aetiological and prognostic subgroup. J Pediatr Surg 2015;50:1739-1745. doi: 10.1016/j.jpedsurg.2015.03.001.

[22] Tezer H, Kanık Yüksek S, Gülhan B, Özkaya Parlakay AN, Tuna Kırsaçlığlu C. Cytomegalovirus hepatitis in 49 pediatric patients with normal immunity. Turk J Med Sci 2016;46:1629-1633. doi: 10.3906/sag-1507-161.

[23] Josephson CD, Caliendo AM, Easley KA, Knezevic A, Shenvi N, Hinkes MT, et al. Blood transfusion and breast milk transmission of cytomegalovirus in very low-birth-weight infants: a prospective cohort study. JAMA Pediatr 2014;168:1054-1062. doi: 10.1001/jamapediatrics.2014.1360.

[24] Kimberlin DW, Lin CY, Sánchez PJ, Demmler GJ, Dankner W, Shelton M, et al. Effect of ganciclovir therapy on hearing in symptomatic congenital cytomegalovirus disease involving the central nervous system: a randomized, controlled trial. J Pediatr 2003;143:16-25. doi: 10.1016/s0022-3476(03)00192-6.

[25] Fischler B, Casswall TH, Malmborg P, Nemeth A. Ganciclovir treatment in infants with cytomegalovirus infection and cholestasis. J Pediatr Gastroenterol Nutr 2002;34:154-157. doi: 10.1097/00005176-200202000-00009.

[26] De Tommaso AM, Andrade PD, Costa SC, Escanhoela CA, Hessel G. High frequency of human cytomegalovirus DNA in the liver of infants with extrahepatic neonatal cholestasis. BMC Infect Dis 2005;5:108. doi: 10 . 1186/1471-2334-5-108. 
[27] Domiati-Saad $R$, Dawson DB, Margraf LR, Finegold MJ, Weinberg AG, Rogers BB. Cytomegalovirus and human herpesvirus 6, but not human papillomavirus, are present in neonatal giant cell hepatitis and extrahepatic biliary atresia. Pediatr Dev Pathol 2000;3:367-373. doi: 10.1007/s100240010045.

[28] Fischler B, Svensson JF, Nemeth A. Early cytomegalovirus infection and the long-term outcome of biliary atresia. Acta Paediatr 2009;98:1600-1602. doi: 10.1111/j.1651-2227.2009.01416.x.

[29] Fjaer RB, Bruu AL, Nordbø SA. Extrahepatic bile duct atresia and vira involvement. Pediatr Transplant 2005;9:68-73. doi: 10.1111/j.1399-3046. 2005.00257.x

[30] Jevon GP, Dimmick JE. Biliary atresia and cytomegalovirus infection: a DNA study. Pediatr Dev Pathol 1999:2:11-14 doi: 10.1007/s100249900083.

[31] Lazim HH, Arif HS, Kadhim HS, Al-Khafaji KR, Abdulghafour KH. The association between biliary atresia and cytomegalovirus hepatitis. J Nepal Paediatr Soc 2015;35:269-273. doi: 10.3126/jnps.v35i3.13547.

[32] Rauschenfels S, Krassmann M, Al-Masri AN, Verhagen W, Leonhardt J Kuebler JF, et al. Incidence of hepatotropic viruses in biliary atresia. Eur J Pediatr 2009;168:469-476. doi: 10.1007/s00431-008-0774-2.

[33] Soomro GB, Abbas Z, Hassan M, Luck N, Memon Y, Khan AW. Is there any association of extra hepatic biliary atresia with cytomegalovirus or other infections? J Pak Med Assoc 2011;61:281-283.

[34] Shen C, Zheng S, Wang W, Xiao XM. Relationship between prognosis of biliary atresia and infection of cytomegalovirus. World J Pediatr 2008;4: 123-126. doi: 10.1007/s12519-008-0024-8.

[35] Tarr PI, Haas JE, Christie DL. Biliary atresia, cytomegalovirus, and age at referral. Pediatrics 1996;97:828-831.

[36] Yaghobi R, Didari M, Gramizadeh B, Rahsaz M, Heidari T, Banihashemi M, et al. Study of viral infections in infants with biliary atresia. Indian J Pediatr 2011;78:478-481. doi: 10.1007/s12098-010-0309-5.

[37] Moore SW, Zabiegaj-Zwick C, Nel E. Problems related to CMV infection and biliary atresia. S Afr Med J 2012;102:890-892. doi: 10.7196/samj.6163.

[38] Chen J, Hu L, Wu M, Zhong T, Zhou YH, Hu Y. Kinetics of IgG antibody to cytomegalovirus (CMV) after birth and seroprevalence of anti-CMV IgG in Chinese children. Virol J 2012;9:304. doi: 10.1186/1743-422X-9-304.

[39] Wen S, Shimizu N, Yoshiyama H, Mizugaki Y, Shinozaki F, Takada K. Association of Epstein-Barr virus (EBV) with Sjögren's syndrome: differential EBV expression between epithelial cells and lymphocytes in salivary glands. Am J Pathol 1996;149:1511-1517.

[40] Incaprera M, Rindi L, Bazzichi A, Garzelli C. Potential role of the Epstein-Barr virus in systemic lupus erythematosus autoimmunity. Clin Exp Rheumatol $1998 ; 16: 289-294$.

[41] Dowd JB, Palermo T, Brite J, McDade TW, Aiello A. Seroprevalence of EpsteinBarr virus infection in U.S. children ages 6-19, 2003-2010. PLoS One 2013; 8:e64921. doi: 10.1371/journal.pone.0064921.

[42] Fleisher G, Bologonese R. Epstein-Barr virus infections in pregnancy: a prospective study. J Pediatr 1984;104:374-379. doi: 10.1016/s0022-3476(84) 81098-7.

[43] Goldberg GN, Fulginiti VA, Ray CG, Ferry P, Jones JF, Cross $\mathrm{H}$, et al. In utero Epstein-Barr virus (infectious mononucleosis) infection. JAM 1981;246 1579-1581. doi: 10.1001/jama.246.14.1579.

[44] Mahjoub F, Shahsiah R, Ardalan FA, Iravanloo G, Sani MN, Zarei A, et al. Detection of Epstein Barr virus by chromogenic in situ hybridization in cases of extra-hepatic biliary atresia. Diagn Pathol 2008;3:19. doi: 10. 1186/1746-1596-3-19.

[45] Weaver LT, Nelson R, Bell TM. The association of extrahepatic bile duct atresia and neonatal Epstein-Barr virus infection. Acta Paediatr Scand 1984;73:155-157. doi: 10.1111/j.1651-2227.1984.tb09918.x.

[46] Kikuchi K, Miyakawa H, Abe K, Fujikawa H, Horiuchi T, Nagai K, et al. Vanishing bile duct syndrome associated with chronic EBV infection. Dig Dis Sci 2000;45:160-165. doi: 10.1023/a:1005434015863.

[47] Chang RS, Seto DS. Perinatal infection by Epstein-Barr virus. Lancet 1979;2: 201.

[48] Gurwith M, Wenman W, Hinde D, Feltham S, Greenberg H. A prospective study of rotavirus infection in infants and young children. J Infect Dis 1981;144:218-224. doi: 10.1093/infdis/144.3.218.

[49] Leung AK, Kellner JD, Davies HD. Rotavirus gastroenteritis. Adv Ther 2005; 22:476-487. doi: 10.1007/BF02849868.

[50] Kelkar SD, Zade JK. Group B rotaviruses similar to strain CAL-1, have been circulating in Western India since 1993. Epidemiol Infect 2004;132:745749. doi: $10.1017 / \mathrm{s} 0950268804002171$.

[51] Rotbart HA, Nelson WL, Glode MP, Triffon TC, Kogut SJ, Yolken RH, et al. Neonatal rotavirus-associated necrotizing enterocolitis: case control study and prospective surveillance during an outbreak. J Pediatr 1988;112:8793. doi: 10.1016/s0022-3476(88)80128-8.

[52] Takahashi S, Oki J, Miyamoto A, Koyano S, Ito K, Azuma H, et al. Encephalopathy associated with haemophagocytic lymphohistiocytosis following rotavirus infection. Eur J Pediatr 1999;158:133-137. doi: 10 . $1007 /$ s004310051033.

[53] Wang W, Donnelly B, Bondoc A, Mohanty SK, McNeal M, Ward R, et al. The rhesus rotavirus gene encoding VP4 is a major determinant in the pathogenesis of biliary atresia in newborn mice. J Virol 2011;85:90699077. doi: 10.1128/JVI.02436-10

[54] Bobo L, Ojeh C, Chiu D, Machado A, Colombani P, Schwarz K. Lack of evidence for rotavirus by polymerase chain reaction/enzyme immunoassay of hepatobiliary samples from children with biliary atresia. Pediatr Res 1997 41:229-234. doi: 10.1203/00006450-199704001-01381.

[55] Clemente MG, Patton JT, Yolken R, Whitington PF, Parashar UD, Jiang B, et al. Prevalence of groups $A$ and $C$ rotavirus antibodies in infants with biliary atresia and cholestatic controls. J Pediatr 2015;166:79-84. doi: 10.1016/j. jpeds.2014.09.033

[56] Riepenhoff-Talty M, Gouvea V, Evans MJ, Svensson L, Hoffenberg E, Sokol RJ, et al. Detection of group $C$ rotavirus in infants with extrahepatic biliary atresia. J Infect Dis 1996;174:8-15. doi: 10.1093/infdis/174.1.8.

[57] Fleming FE, Graham KL, Takada Y, Coulson BS. Determinants of the specificity of rotavirus interactions with the alpha2beta1 integrin. J Biol Chem 2011 286:6165-6174. doi: 10.1074/jbc.M110.142992.

[58] Jafri M, Donnelly B, Allen S, Bondoc A, McNeal M, Rennert PD, et al. Cholangiocyte expression of alpha2beta1-integrin confers susceptibility to rotavirusinduced experimental biliary atresia. Am J Physiol Gastrointest Liver Physio 2008;295:G16-G26. doi: 10.1152/ajpgi.00442.2007.

[59] Hertel PM, Estes MK. Rotavirus and biliary atresia: can causation be proven? Curr Opin Gastroenterol 2012;28:10-17. doi: 10.1097/MOG. 0b013e32834c7ae4.

[60] Abdel-Moneim AS, Al-Malky MI, Alsulaimani AA, Abuelsaad AS, Mohamed I, Ismail AK. Sequence diversity of VP4 and VP7 genes of human rotavirus strains in Saudi Arabia. Foodborne Pathog Dis 2015;12:937-944. doi: 10. 1089/fpd.2015.1990.

[61] Morecki R, Glaser JH, Johnson AB, Kress Y. Detection of reovirus type 3 in the porta hepatis of an infant with extrahepatic biliary atresia: ultrastructural and immunocytochemical study. Hepatology 1984;4:1137-1142. doi: 10. 1002/hep. 1840040608

[62] Stanley NF, Joske RA. Animal model of human disease. Chronic biliary obstruction. Animal model: Chronic biliary obstruction caused by Reovirus type 3. Am J Pathol 1975;80:185-188.

[63] Papadimitriou JM. The biliary tract in acute murine reovirus 3 infection. Light and electron microscopic study. Am J Pathol 1968;52:595-611.

[64] Rosenberg DP, Morecki R, Lollini LO, Glaser J, Cornelius CE. Extrahepatic biliary atresia in a rhesus monkey (Macaca mulatta). Hepatology 1983;3: 577-580. doi: 10.1002/hep.1840030417.

[65] Saito T, Shinozaki K, Matsunaga T, Ogawa T, Etoh T, Muramatsu T, et al. Lack of evidence for reovirus infection in tissues from patients with biliary atresia and congenital dilatation of the bile duct. J Hepatol 2004;40:203-211. doi: 10.1016/j.jhep.2003.10.025

[66] Steele MI, Marshall CM, Lloyd RE, Randolph VE. Reovirus 3 not detected by reverse transcriptase-mediated polymerase chain reaction analysis of preserved tissue from infants with cholestatic liver disease. Hepatology 1995 ; 21:697-702. doi: 10.1016/0270-9139(95)90520-0.

[67] Tyler KL, Sokol RJ, Oberhaus SM, Le M, Karrer FM, Narkewicz MR, et al. Detection of reovirus RNA in hepatobiliary tissues from patients with extrahepatic biliary atresia and choledochal cysts. Hepatology 1998;27:14751482. doi: 10.1002/hep.510270603.

[68] Bisaillon M, Bergeron J, Lemay G. Characterization of the nucleoside triphosphate phosphohydrolase and helicase activities of the reovirus lambda1 protein. J Biol Chem 1997;272:18298-18303. doi: 10.1074/jbc.272.29. 18298

[69] Wiener JR, Joklik WK. The sequences of the reovirus serotype 1, 2, and 3 L1 genome segments and analysis of the mode of divergence of the reovirus serotypes. Virology 1989;169:194-203. doi: 10.1016/0042-6822(89) 90055-x.

[70] Broering TJ, Kim J, Miller CL, Piggott CD, Dinoso JB, Nibert ML, et al. Reovirus nonstructural protein mu NS recruits viral core surface proteins and entering core particles to factory-like inclusions. J Virol 2004;78:1882-1892. doi: 10 . 1128/jvi.78.4.1882-1892.2004.

[71] Becker MM, Goral MI, Hazelton PR, Baer GS, Rodgers SE, Brown EG, et al. Reovirus sigmaNS protein is required for nucleation of viral assembly complexes and formation of viral inclusions. J Virol 2001;75:1459-1475. doi: 10 . 1128/JVI.75.3.1459-1475.2001.

[72] Goral MI, Mochow-Grundy M, Dermody TS. Sequence diversity within the reovirus S3 gene: reoviruses evolve independently of host species, geographic locale, and date of isolation. Virology 1996;216:265-271. doi: 10 1006/viro.1996.0059.

[73] McCutcheon AM, Broering TJ, Nibert ML. Mammalian reovirus M3 gene sequences and conservation of coiled-coil motifs near the carboxyl terminus of the microNS protein. Virology 1999;264:16-24. doi: 10.1006/viro.1999. 9990.

[74] Kilgore A, Mack CL. Update on investigations pertaining to the pathogenesis of biliary atresia. Pediatr Surg Int 2017;33:1233-1241. doi: 10. 1007/s00383-017-4172-6.

[75] Takeda K, Akira S. Toll-like receptors in innate immunity. Int Immunol 2005 17:1-14. doi: 10.1093/intimm/dxh186. 
Averbukh L.D. et al: Viral biliary atresia: A review

[76] Saito T, Hishiki T, Terui K, Mitsunaga T, Terui E, Nakata M, et al. Toll-like receptor mRNA expression in liver tissue from patients with biliary atresia. J Pediatr Gastroenterol Nutr 2011;53:620-626. doi: 10.1097/MPG.0b013e3182307c9c.

[77] Illescas O, Gomez-Verjan JC, García-Velázquez L, Govezensky T, RodriguezSosa M. Macrophage migration inhibitory factor $-173 \mathrm{G} / \mathrm{C}$ polymorphism: A global meta-analysis across the disease spectrum. Front Genet 2018;9:55. doi: 10.3389/fgene.2018.00055.

[78] Squires JE, Shivakumar P, Mourya R, Bessho K, Walters S, Bezerra JA Natural killer cells promote long-term hepatobiliary inflammation in a lowdose rotavirus model of experimental biliary atresia. PLoS One 2015;10: e0127191. doi: 10.1371/journal.pone.0127191.

[79] Saxena V, Shivakumar P, Sabla G, Mourya R, Chougnet C, Bezerra JA. Dendritic cells regulate natural killer cell activation and epithelial injury in experimental biliary atresia. Sci Transl Med 2011;3:102r-94. doi: 10. 1126/scitransImed.3002069.

[80] Qiu $Y$, Yang J, Wang W, Zhao W, Peng F, Xiang $Y$, et al. HMGB1-promoted and TLR2/4-dependent NK cell maturation and activation take part in rotavirusinduced murine biliary atresia. PLoS Pathog 2014;10:e1004011. doi: 10. 1371/journal.ppat.1004011.

[81] Shivakumar P, Campbell KM, Sabla GE, Miethke A, Tiao G, McNeal MM, et al. Obstruction of extrahepatic bile ducts by lymphocytes is regulated by IFNgamma in experimental biliary atresia. J Clin Invest 2004;114:322-329. doi: $10.1172 / J C I 21153$

[82] Ohya T, Fujimoto T, Shimomura H, Miyano T. Degeneration of intrahepatic bile duct with lymphocyte infiltration into biliary epithelial cells in biliary atresia. J Pediatr Surg 1995;30:515-518. doi: 10.1016/0022-3468(95)90120-5.

[83] Hill R, Quaglia A, Hussain M, Hadzic N, Mieli-Vergani G, Vergani D, et al. Th17 cells infiltrate the liver in human biliary atresia and are related to surgical outcome. J Pediatr Surg 2015;50:1297-1303. doi: 10.1016/j.jpedsurg. 2015.02.005.

[84] Klemann C, Schröder A, Dreier A, Möhn N, Dippel S, Winterberg T, et al. Interleukin 17 , produced by $\gamma \delta$ T cells, contributes to hepatic inflammation in a mouse model of biliary atresia and is increased in livers of patients. Gastroenterology 2016;150:229-241.e5. doi: 10.1053/j.gastro.2015.09.008.

[85] Lu BR, Brindley SM, Tucker RM, Lambert CL, Mack CL. $\alpha$-enolase autoantibodies cross-reactive to viral proteins in a mouse model of biliary atresia. Gastroenterology 2010;139:1753-1761. doi: 10.1053/j.gastro.2010.07. 042.

[86] Fujinami RS, von Herrath MG, Christen U, Whitton JL. Molecular mimicry, bystander activation, or viral persistence: infections and autoimmune disease. Clin Microbiol Rev 2006;19:80-94. doi: 10.1128/CMR.19.1.8094.2006.

[87] Dong H, Qu S, Chen X, Zhu H, Tai X, Pan J. Changes in the cytokine expression of peripheral Treg and Th17 cells in children with rotavirus enteritis. Exp Ther Med 2015;10:679-682. doi: 10.3892/etm.2015.2511.

[88] Brindley SM, Lanham AM, Karrer FM, Tucker RM, Fontenot AP, Mack CL. Cytomegalovirus-specific T-cell reactivity in biliary atresia at the time of diagnosis is associated with deficits in regulatory T cells. Hepatology 2012; 55:1130-1138. doi: 10.1002/hep.24807.

[89] Li K, Zhang X, Yang L, Wang XX, Yang DH, Cao GQ, et al. Foxp3 promoter methylation impairs suppressive function of regulatory $T$ cells in biliary atresia. Am J Physiol Gastrointest Liver Physiol 2016;311:G989-G997. doi: 10.1152/ajpgi.00032.2016.

[90] Dong R, Zhao R, Zheng S. Changes in epigenetic regulation of CD4+ T lymphocytesin biliary atresia. Pediatr Res 2011;70:555-559. doi: 10.1203/PDR. Ob013e318232a949. 